\title{
PENGEMBANGAN DAN PENGUJIAN VALIDITAS BUTIR INSTRUMEN KECERDASAN LOGIS-MATEMATIS
}

\author{
Komang Setemen \\ Fakultas Teknik dan Kejuruan, Universitas Pendidikan Ganesha \\ email: k.setemen@undiksha.ac.id
}

\begin{abstract}
Abstrak
Tujuan dari penelitian ini adalah untuk mengembangkan dan melakukan pengujian validitas butir terhadap instrumen kecerdasan logis-matematis. Instrumen kecerdasan logis-matematis yang dikembangkan mengadopsi teori dari Howard Gardner dan indikator-indikator yang dikembangkan oleh Paul Suparno. Butir-butir instrumen diturunkan dari delapan indikator pada variabel kecerdasan logis-matematis. Ujicoba instrumen dilakukan di Jurusan Manajemen Informatika FTK Undiksha. Subjek ujicoba adalah mahasiswa semester 3 yang sudah mengambil matakuliah pemrograman komputer dan berjumlah 60 orang. Metode analisis datanya adalah: 1) validasi konsep dari 2 orang pakar pada bidang informatika, dan 2) validasi empirik pada sampel yang telah ditentukan sebagai ujicoba instrumen. Validitas butir instrumen dihitung dengan menggunakan korelasi product moment, sedangkan untuk reliabilitas dihitung dengan Alpha-Cronbach. Berdasarkan hasil pengujian validitas butir, diperoleh butir yang valid sebanyak 37 butir dan tidak valid sebanyak 3 butir. Koefisien reliabilitas diperoleh sebesar $r_{11}=0,853$. Dengan demikian, koefisien reliabilitas instrumen lebih besar dari 0,7 , sehingga dapat digunakan lebih lanjut.
\end{abstract}

Kata kunci: pengembangan instrumen, kecerdasan logis-matematis, validitas butir

\begin{abstract}
The purpose of this study was to develop and test the validity of logical-mathematical intellegence instruments. The logical-mathematical intellegence instrument which developed was adopting from the theory of Howard Gardner and all of the indicators made by Paul Suparno. The items of instrument are derived from the eight indicators in the logical-mathematical intelligence variables. Implementation of trials was conducted in the Department of Informatics Management FTK Undiksha. Test subjects in this study were 3rd semester students in informatics management who have ever take computer programming courses and they were 60 students. The Data analysis methods which used were: 1) validation of the concept of two experts in informatics, and 2) empirical validation performed on a sample which is used as a test instrument. The validity of logical-mathematical instruments was calculated by using product moment correlation, whereas for reliability it's calculated by Cronbach's Alpha. Based on the test results of the validity of the instrument logical-mathematical intelligence was obtained valid items as much as 37 items and as much as 3 items invalid. The coefficient of reliability was obtained for $r_{11}=0.853$. So, the test results showed that the coefficient of reliability of the instrument logical-mathematical intelligence was greater than 0.7 , so it can be used further.
\end{abstract}

Keywords: instrument development, logical-mathematical intellegence, item validity

\section{PENDAHULUAN}

Membuat program komputer bagi sebagian orang adalah hobi, dan sebagian lainnya adalah adanya tuntutan dari pekerjaan. Kemampuan membuat program dari setiap orang yang menekuni pemrograman bervariasi. Hal ini dapat disebabkan karena pengalaman setiap orang berbeda, ataupun cara belajar setiap orang berbeda. Ada yang belajar secara otodidak melalui referensi-referensi yang ada, naun ada pula yang belajar dengan menempuh pendidikan formal di perguruan tinggi. Banyak hal yang mempengaruhi keberhasilan setiap orang, siswa atau mahasiswa terkait pemrograman. Diantaranya adalah sumber referensi, faktor pengajar, metode 
yang diterapkan termasuk jenis penilaiannya, serta tingkat kecerdasan setiap orang atau mahasiswa. Salah satu fakta yang diungkapkan oleh Setemen (2014, 38-42) bahwa, jenis asesmen yang digunakan pada saat proses pembelajaran pemrograman komputer berlangsung, ternyata berpengaruh terhadap hasil akhir belajar pemrograman komputer.

Hal lain yang perlu juga diperhatikan dalam keberhasilan pembelajaran pemrograman adalah karakteristik pebelajar atau mahasiswa. Karakteristik mahasiswa sangat bervariasi, yang mana tentunya akan memiliki kemampuan yang berbeda-beda dalam merefleksikan dirinya dalam proses pembelajaran. Hasil refleksi ini akan mencerminkan perbedaan setiap individu (individual difference) yang merupakan ciri dari kecerdasan ganda/majemuk (multiple intelligence) yang mana dalam konteks pembelajaran pemrograman komputer adalah kecerdasan logis-matematis. Sehingga dengan demikian akan nampak nantinya hasil perkembangan belajar mahasiswa dengan kecerdasan logis-matematis tinggi dengan mahasiswa yang mempunyai kecerdasan logis-matematis rendah. Oleh karena kecerdasan setiap orang berbedabeda, maka cara yang dilakukan oleh orang yang satu dengan yang lainnya akan berbeda pula dalam mencapai tujuan belajarnya.

Saat ini, kecerdasan seseorang dalam kehidupan nyata selalu dihubungkan dengan IQ (intelligence quotient). IQ yang diungkapkan oleh banyak ahli psikologi pada hakikatnya hanya berdimensi logis-matematis dan linguistik. Jadi, pada IQ sebetulnya hanya menjelaskan kemampuan menggunakan angka, rumus-rumus, logika, dan penerapan bahasa. Sehingga orang dikenal ber-IQ tinggi merupakan orang yang mampu menggunakan angka, rumus, logika, dan penerapan bahasa.

Gardner mendefinisikan bahwa kecerdasan sebagai sebuah kemampuan dalam memecahkan masalah serta menghasilkan produk pada seting yang bermacam-macam dalam situasi nyata (Suparno, 2004:17). Dalam pengertian tersebut jelas bahwa, kecerdasan tidak hanya kemampuan yang dimiliki seseorang untuk dapat menjawab tes IQ dalam keadaan terisolasi dan lepas dari lingkungannya. Kecerdasan memuat kemampuan-kemampuan untuk memecahkan permasalahan yang nyata pada situasi yang bermacam-macam. Bagi Gardner seseorang sungguh memiliki kecerdasan tinggi apabila orang tersebut dapat menyelesaikan permasalahan hidup yang nyata, bukan hanya sekedar dalam teori. Makin tinggi kecerdasannya bila dapat memecahkan permasalahan dalam hidupnya dan dalam situasi yang bermacam-macam, karena situasi nyata dalam hidup sungguh kompleks. Maka, untuk dapat mengerti menonolnya kecerdasan seseorang, perlu dilihat juga bagaimana seseorang itu menghadapi persoalan-persolan nyata dalam hidupnya, bukan saja hanya dengan sebuah tes di atas meja.

Bagi Gardner, kecerdasan setiap orang itu tidak tunggal tetapi jamak. Inilah yang ditemukan Gardner dan rekanrekannya di Harvard University terkait dengan kecerdasan manusia (Suparno, 2004:14). Temuan penelitian inilah yang selanjutnya disebut dengan teori Multiple Intellegences. Teori kecerdasan majemuk (multiple intelligences) ini ditemukan dan dikembangkan oleh Howard Gardner, yang merupakan seorang ahli psikologi perkembangan dan profesor pendidikan dari Graduate School of Education, Harvard University, Amerika Serikat. Gardner mulai menuliskan gagasan tentang kecerdasan majemuk dalam buku yang berjudul Frame of Mind tahun 1983. Tahun 1993 Gardner mempublikasikan buku yang berjudul Multiple Intelligences, setelah berhasil melakukan banyak penelitian yang berkaitan dengan implikasi dari teori kecerdasan majemuk dalam dunia pendidikan. Teori tersebut dilengkapi lagi dengan terbitnya buku Intelligence Reframed pada tahun 2000.

Penelitian yang dilakukan Gardner menyebutkan bahwa, ada 8 (delapan) macam kecerdasan manusia dalam memahami dunia nyata (Budiningsih, 2012:114). Yang mana hasil penelitian ini melahirkan teori yang disebut dengan multiple intelligences (kecerdasan 
majemuk). Lebih lanjut dikatakan bahwa, pada dasarnya satu kecerdasan akan lebih menonjol atau lebih kuat daripada yang lain. Hal ini dapat dimaknai bahwa, setiap orang adalah berbeda sehingga memperlakukan sejumlah orang dengan perlakuan yang sama tidaklah tepat.

Pada awal penelitiannya, Gardner telah mengumpulkan banyak sekali kemampuan-kemampuan manusia yang sekiranya dapat dimasukkan ke dalam pengertian tentang kecerdasan. Setelah semua kemampuan itu dianalisis secara teliti, akhirnya dia menerima adanya delapan kecerdasan yang ada dan dimiliki manusia, yaitu: 1) kecerdasan linguistik (linguistic intelligence), 2) kecerdasan matematis-logis (logical-mathematical intelligence), 3) kecerdasan ruang-visual (visual-spatial intelligence), 4) kecerdasan kinestetik-badani (bodily-kinesthetic intelligence), 5) kecerdasan musikal (musical intelligence), 6) kecerdasan interpersonal (interpersonal intelligence), 7) kecerdasan intrapersonal (intrapersonal intelligence), dan 8) kecerdasan lingkungan atau naturalis (naturalist intelligence) (Suparno, 2004:19).

Dalam konteks pemrograman komputer, dari delapan kecerdasan yang sudah disebutkan di atas, yang perlu menjadi perhatian dan diarahkan oleh pendidik adalah kecerdasan logismatematis. Kecerdasan logis-matematis sangat dibutuhkan dalam proses pemrograman, karena untuk dapat membuat program, seseorang harus dapat memahami logika proses (process logic) dari sebuah permasalahan. Tanpa memahami logika proses dari sebuah masalah, maka akan sulit untuk menterjemahkan masalah tersebut menjadi sebuah program komputer. Sementara itu, dalam proses pemrograman, pemahaman akan matematika juga sangat dibutuhkan. Pemahaman matematika erat kaitannya dengan proses pemberian nilai pada suatu variabel atau penggunaan operator pada suatu proses logika. Contoh nyata dari pemahaman matematika adalah berkaitan dengan aljabar Boolean. Nilai fungsi Boolean dinyatakan dengan angka '0' atau ' 1 ' atau dalam bahasa program bernilai 'false' atau 'true'. Dalam sebuah program komputer aplikasi fungsi Boolean ini digunakan untuk menyatakan suatu variabel bernilai 'false' atau 'true' untuk kemudian dapat dilakukan sebuah keputusan sebagai akibat dari kondisi tersebut. Dan masih banyak lagi teori-teori matematika untuk dapat diterapkan dalam pemrograman komputer. Oleh karena itu, kecerdasan logis-matematis sangat dibutuhkan dalam membuat program komputer.

Kecerdasan logis-matematis merupakan kemampuan logika dan matematika, disamping kemampuan ilmu pengetahuan alam (Gardner, 2003: 23). Kecerdasan logis-matematis merupakan kemampuan seseorang yang erat kaitannya dengan penggunaan bilanganbilangan dan kemampuan logika dengan efektif. Orang dengan kemampuan seperti ini, contohnya adalah ahli matematika, ilmuwan bidang sains, pemrogram komputer, dan para logikawan. Individu atau orang yang memiliki intelegensi seperti ini, akan peka pada sesuatu yang bersifat logis, sesuatu yang abstrak, klasifikasi atau kategorisasi, dan termasuk pula pada sesuatu yang bersifat perhitungan-perhitungan. Orang dengan inteligensi logis-matematis akan sangat dengan mudah melakukan pengklasifikasian dan pengkategorisasian dalam berfikir dan bekerja (Suparno, 2004:29). Menurut Iskandar, kecerdasan logis-matematis merupakan kemampuan seseorang yang memuat cara berpikir induktif maupun deduktif, berpikir sesuai aturan logika, dapat menggunakan kemampuan berpikir dalam menyelesaikan masalah serta dapat memahami dan menganalisa pola-pola pada suatu angka-angka (Iskandar, 2012:54). Sementara itu, Jasmine menyampaikan bahwa, kecerdasan logismatematis berkaitan dan mencakup kemampuan ilmiah (Jasmine, 2012:19). Lebih spesifik Riyanto menyampaikan bahwa, kecerdasan logis-matematis merupakan kemampuan memanfaatkan angka secara baik (seperti, matematikawan, akuntan dan statistikawan) serta dapat melakukan penalaran dengan benar contohnya 
adalah seorang ilmuwan, programmer, atau seorang logikus (Riyanto, 2010:237). Kecerdasan logis-matematis menurut Armstrong adalah bagaimana seseorang mampu menggunakan angka dengan efektif dengan alasan yang baik. Kecerdasan ini memuat kepekaan dan hubungan yang logis terhadap pola-pola, dalil dan pernyataan, serta fungsi, dan sesuatu yang bersifat abstrak (Armstrong, 2013:8). Lain lagi dengan pendapat Budiningsih, bahwa kecerdasan logismatematis sering disebut sebagai berpikir ilmiah, termasuk di dalamnya berpikir secara induktif maupun deduktif (Budiningsih, 2012:114).

Berdasarkan ulasan itu, maka untuk mengetahui kecerdasan logis-matematis individu dalam belajar pemrograman komputer perlu dilakukan sebuah pengukuran. Pengukuran kecerdasan logis-matematis yang dimiliki oleh setiap individu yang belajar pemrograman, memerlukan sebuah instrumen dalam prosesnya. Dengan adanya instrumen untuk mengukur tingkat kecerdasan logismatematis individu, maka akan dapat dilakukan perlakuan yang berbeda dalam proses pembelajaran pemrograman komputer. Perlakuan yang dimaksud adalah dapat berupa perbedaan metode pembelajaran maupun cara melakukan asesmen dalam menilai hasil belajar pemrograman komputer.

Berdasarkan hal-hal yang telah diungkapkan sebelumnya, maka dalam penelitian ini dilakukan pengembangan instrumen kecerdasan logis-matematis, uji validitas isi oleh pakar, ujicoba instrumen untuk menentukan butir-butir yang valid, dan selanjutnya perhitungan reliabilitas instrumen.

\section{METODE}

Penelitian ini dilakukan dengan tujuan untuk mengembangkan dan menguji validitas setiap butir instrumen kecerdasan logis-matematis. Penelitian ini diawali dengan kajian teori tentang kecerdasan logis-matematis, kemudian dilakukan sintesis teori dalam bentuk definisi konsep dan definisi operasional. Ada lima tahapan yang dilakukan dalam pengembangan instrumen kecerdasan logis-matematis ini. Lima langkah tersebut adalah sebagai berikut: (1) menyusun definisi konseptual, (2) menyusun definisi operasional, (3) menyusun kisi-kisi instrumen yang mengacu pada indikatorindikator yang ada, (4) menyusun butirbutir instrumen, dan (5) melakukan pengujian validitas dan penghitungan reliabilitas.

Proses pengujian validitas dilakukan dengan dua tahapan, yaitu: 1) validasi konsep, bertujuan untuk melakukan telaah ketepatan butir-butir instrumen yang dilihat dari isi, konstruksi dan kebahasaan berdasarkan penilaian yang dilakukan oleh pakar, dan 2) validasi empirik, bertujuan untuk menguji ketepatan butir-butir instrumen dan kehandalan instrumen berdasarkan atas ujicoba terhadap sampel yang telah ditetapkan dalam penelitian. Jumlah sampel yang dijadikan ujicoba sebanyak 60 orang mahasiswa.

\section{HASIL DAN PEMBAHASAN}

\section{Definisi Konseptual}

Kecerdasan logis-matematis adalah kemampuan yang berkaitan dengan penggunaan bilangan dan logika secara efektif.

\section{Definisi Operasional}

Kecerdasan logis-matematis adalah skor kemampuan yang berkaitan dengan penggunaan bilangan dan logika secara efektif, yang dapat diukur dengan indikator-indikator: 1) suka menanyakan tentang bagaimana suatu benda bekerja, 2) suka berpikir dengan logika yang jelas, 3) menghitung secara cepat, 4) menyukai kelas matematika dan IPA, 5) menyukai permainan matematis dalam komputer, 6) suka mengatur berbagai hal secara teratur, kategoris, dan hirarkis, 7) berpikir lebih abstrak dan konseptual, dan 8) punya kepekaan dengan sebab-akibat dalam suatu persoalan.

$\begin{array}{lr}\text { Kisi-kisi Instrumen } & \\ \text { Pengembangan } & \text { instrumen } \\ \text { kecerdasan logis-matematis, } & \text { diawali } \\ \text { dengan rancangan berupa } & \text { kisi-kisi } \\ \text { instrumen yang selanjutnya } & \text { disebut }\end{array}$


kuesioner kecerdasan logis-matematis. Kuesioner ini berisi butir-butir pernyataan yang diturunkan dari penjabaran indikatorindikator kecerdasan logis-matematis berdasarkan teori yang diadopsi. Setiap butir dalam pernyataan merupakan suatu keadaan atau kecenderungan perasaan responden berkaitan dengan kecerdasan logis-matematis. Butir-butir pernyataan tersebut disertai dengan lima pilihan jawaban, yaitu: sangat setuju (SS), setuju (S), kurang setuju (KS), tidak setuju (TS), dan sangat tidak setuju (STS).

Kisi-kisi instrumen untuk mengukur kecerdasan logis-matematis tampak seperti pada Tabel 1.

Tabel 1. Kisi-kisi instrumen

\begin{tabular}{|c|c|c|c|}
\hline Indikator & $\begin{array}{l}\text { Butir } \\
\text { Positif }\end{array}$ & $\begin{array}{l}\text { Butir } \\
\text { Negatif }\end{array}$ & Jumlah \\
\hline $\begin{array}{l}\text { 1. Suka menanyakan tentang bagaimana suatu benda } \\
\text { bekerja }\end{array}$ & $1,3,23$ & 2,4 & 5 \\
\hline 2. Suka berpikir dengan logika yang jelas & $6,24,25$ & 5,26 & 5 \\
\hline 3. Suka berpikir dengan logika yang jelas & $8,27,28$ & 7,29 & 5 \\
\hline 4. Menyukai kelas matematika dan IPA & $9,10,30$ & 11,12 & 5 \\
\hline 5. Menyukai permainan matematis dalam komputer & $13,14,31$ & 15,16 & 5 \\
\hline $\begin{array}{l}\text { 6. Suka mengatur berbagai hal secara teratur, kategoris, dan } \\
\text { hirarkis }\end{array}$ & $17,18,32$ & 19,20 & 5 \\
\hline 7. Berpikir lebih abstrak dan konseptual & $21,33,34$ & 35,36 & 5 \\
\hline $\begin{array}{l}\text { 8. Punya kepekaan dengan sebab-akibat dalam suatu } \\
\text { persoalan }\end{array}$ & $22,37,38$ & 39,40 & 5 \\
\hline Jumlah & 24 & 16 & 40 \\
\hline
\end{tabular}

\section{Validasi Instrumen}

Validasi dilakukan dengan dua tahapan, yaitu: 1) validasi konsep, bertujuan untuk melakukan telaah ketepatan butir-butir instrumen yang dilihat dari isi, konstruksi dan kebahasaan berdasarkan penilaian yang dilakukan oleh pakar, dan 2) validasi empirik, bertujuan untuk menguji ketepatan butir-butir instrumen dan kehandalan instrumen berdasarkan atas ujicoba terhadap sampel yang telah ditetapkan dalam penelitian.

Validitas isi yang digunakan dalam penilaian pakar, menggunakan rumus Gregory (Gregory, 2000: 98). Adapun catatan-catatan yang diberikan oleh kedua pakar adalah masalah struktur bahasa yang digunakan, seperti menghilangkan kata tidak pada pernyataan negatif dan dianjurkan untuk menggunakan kalimat yang lebih singkat. Butir-butir yang menjadi catatan oleh kedua pakar adalah nomor butir 2, 12, 16, 17, 29, 31 dan butir 37.

Berdasarkan hasil penilaian pakar terhadap instrumen kemudian diperbaiki sesuai dengan masukan yang diberikan berkaitan dengan kesesuaian butir dengan indikator, kesesuaian indikator dengan materi, dan kesesuaian penggunaan bahasa serta kesesuaian butir soal dengan responden. Validitas isi yang digunakan dalam penilaian pakar, menggunakan rumus Gregory dengan mekanisme: 1) Para pakar yang ditunjuk melakukan penilaian terhadap instrumen dengan mengklasifikasikan butir soal menjadi sangat relevan (skor 3 atau 4) dan kurang relevan (skor 1 atau 2) seperti pada Tabel 2), 2) hasil penilaian pakar ditabulasi dalam bentuk matriks $2 \times 2$ (seperti pada Tabel 3, 3) dibuat tabulasi silang, dan 4) dilakukan perhitungan validitas isi dengan rumus berikut.

$$
C V=\frac{D}{A+B+C+D} \text { (Gregory, 2000:98) }
$$

Keterangan:

$\mathrm{CV}=$ Content Validity

$\mathrm{A}=$ banyaknya item menurut kedua pakar kurang relevan 

$\mathrm{B}=$ banyaknya item yang dianggap sangat relevan oleh pakar I dan kurang relevan oleh pakar II
C = banyaknya item yang dianggap kurang relevan oleh pakar I dan sangat relevan oleh pakar II
$\mathrm{D} \quad=$ banyaknya item yang dianggap sangat relevan oleh kedua pakar

Tabel 2. Skor penilaian kedua pakar

\begin{tabular}{|l|c|c|c|c|c|c|c|c|c|c|c|c|c|c|c|c|c|c|c|c|}
\hline item & 1 & 2 & 3 & 4 & 5 & 6 & 7 & 8 & 9 & 10 & 11 & 12 & 13 & 14 & 15 & 16 & 17 & 18 & 19 & 20 \\
\hline I & 4 & 4 & 3 & 4 & 2 & 4 & 4 & 3 & 3 & 3 & 4 & 3 & 3 & 3 & 4 & 4 & 3 & 3 & 4 & 4 \\
\hline II & 4 & 3 & 3 & 4 & 3 & 4 & 4 & 3 & 4 & 3 & 4 & 3 & 3 & 3 & 3 & 4 & 3 & 3 & 4 & 4 \\
\hline Item & 21 & 22 & 23 & 24 & 25 & 26 & 27 & 28 & 29 & 30 & 31 & 32 & 33 & 34 & 35 & 36 & 37 & 38 & 38 & 40 \\
\hline I & 4 & 4 & 3 & 4 & 2 & 4 & 4 & 3 & 3 & 3 & 3 & 4 & 3 & 3 & 3 & 4 & 4 & 3 & 3 & 4 \\
\hline II & 3 & 4 & 4 & 4 & 3 & 4 & 2 & 3 & 3 & 4 & 3 & 3 & 4 & 4 & 3 & 3 & 4 & 3 & 3 & 3 \\
\hline
\end{tabular}

Tabel 3. Tabulasi silang $2 \times 2$

\begin{tabular}{|l|c|c|c|}
\cline { 3 - 4 } \multicolumn{2}{c}{ Tabulasi Silang 2x2 } & \multicolumn{2}{c|}{ Rater I } \\
\cline { 3 - 4 } \multicolumn{2}{c|}{} & $\begin{array}{c}\text { Kurang Relevan } \\
\text { (skor 1 atau 2) }\end{array}$ & $\begin{array}{c}\text { Sangat Relevan } \\
\text { (skor 3 atau 4) }\end{array}$ \\
\hline \multirow{2}{*}{ Rater II } & $\begin{array}{c}\text { Kurang Relevan } \\
\text { (skor 1 atau 2) } \\
\text { (skor 3 atau 4) }\end{array}$ & A & B \\
\cline { 2 - 4 } & $\begin{array}{c}\text { Sangat Relevan } \\
\text { (skor }\end{array}$ & C & D \\
\hline
\end{tabular}

Berdasarkan skor yang diperoleh pada Tabel 1 dan hasil tabulasi pada Tabel 2, maka diperoleh jumlah skor untu $A=0, B=1, \quad C=2$, dan $D=37$. Dengan demikian hasil perhitungan menggunakan rumus Gregory diperoleh nilai $C V=0,92$. Ini berarti bahwa penilaian kedua pakar terhadap kuesioner kecerdasan logismatematis, diperoleh koefisien validitas isi sama dengan 0,92 . Karena validitas isi lebih besar dari 0,9, maka instrumen sudah dapat diujikan lebih lanjut.

Langkah selanjutnya adalah ujicoba instrumen pada responden. Instrumen kecerdasan logis-matematis ini diujicobakan pada 60 orang mahasiswa sebagai sampel. Ringkasan skor hasil ujicoba seperti pada Tabel 3 berikut.

Tabel 3. Ringkasan skor hasil ujicoba

\begin{tabular}{|l|c|c|c|c|c|c|c|c|c|c|c|c|c|c|c|c|c|c|c|c|}
\hline Item & 1 & 2 & 3 & 4 & 5 & 6 & 7 & 8 & 9 & 10 & 11 & 12 & 13 & 14 & 15 & 16 & 17 & 18 & 19 & 20 \\
\hline R1 & 3 & 4 & 4 & 1 & 1 & 4 & 4 & 4 & 2 & 4 & 4 & 2 & 2 & 3 & 3 & 3 & 2 & 5 & 2 & 2 \\
\hline R2 & 3 & 5 & 5 & 3 & 4 & 5 & 4 & 2 & 2 & 5 & 2 & 3 & 4 & 3 & 3 & 4 & 5 & 4 & 3 & 2 \\
\hline R3 & 4 & 3 & 4 & 2 & 2 & 3 & 3 & 3 & 4 & 3 & 3 & 2 & 3 & 4 & 4 & 5 & 4 & 5 & 4 & 3 \\
\hline R4 & 3 & 4 & 4 & 3 & 4 & 4 & 3 & 3 & 2 & 5 & 3 & 3 & 4 & 5 & 3 & 4 & 2 & 5 & 4 & 2 \\
\hline R5 & 4 & 4 & 4 & 3 & 4 & 4 & 4 & 2 & 3 & 3 & 2 & 3 & 4 & 3 & 4 & 2 & 3 & 2 & 3 & 3 \\
\hline R6 & 2 & 3 & 1 & 1 & 1 & 1 & 1 & 1 & 3 & 1 & 1 & 3 & 1 & 1 & 1 & 2 & 2 & 1 & 1 & 3 \\
\hline R7 & 5 & 3 & 5 & 5 & 3 & 4 & 4 & 3 & 4 & 3 & 3 & 1 & 3 & 1 & 3 & 3 & 1 & 5 & 5 & 2 \\
\hline R8 & 3 & 3 & 4 & 4 & 3 & 3 & 3 & 3 & 3 & 3 & 2 & 3 & 2 & 3 & 4 & 3 & 2 & 5 & 4 & 3 \\
\hline R9 & 4 & 3 & 3 & 3 & 4 & 5 & 4 & 4 & 3 & 2 & 4 & 5 & 3 & 4 & 4 & 4 & 3 & 5 & 3 & 4 \\
\hline R10 & 3 & 3 & 5 & 3 & 1 & 1 & 3 & 2 & 1 & 2 & 2 & 2 & 3 & 2 & 3 & 4 & 2 & 4 & 4 & 2 \\
\hline R11 & 4 & 5 & 5 & 4 & 1 & 5 & 2 & 4 & 4 & 4 & 5 & 5 & 5 & 5 & 4 & 4 & 4 & 5 & 5 & 3 \\
\hline R12 & 3 & 4 & 2 & 2 & 2 & 3 & 2 & 2 & 3 & 3 & 4 & 3 & 4 & 4 & 2 & 5 & 2 & 5 & 3 & 2 \\
\hline R13 & 3 & 3 & 5 & 5 & 3 & 2 & 2 & 3 & 2 & 4 & 1 & 4 & 4 & 1 & 1 & 3 & 3 & 5 & 5 & 2 \\
\hline R14 & 4 & 3 & 3 & 3 & 3 & 4 & 3 & 2 & 3 & 4 & 2 & 2 & 4 & 2 & 2 & 2 & 2 & 4 & 4 & 3 \\
\hline R15 & 3 & 5 & 4 & 2 & 3 & 4 & 2 & 2 & 1 & 4 & 2 & 2 & 3 & 2 & 2 & 5 & 2 & 4 & 4 & 3 \\
\hline R16 & 4 & 4 & 4 & 5 & 3 & 3 & 4 & 5 & 1 & 3 & 3 & 4 & 4 & 3 & 1 & 5 & 4 & 3 & 3 & 5 \\
\hline R17 & 4 & 5 & 5 & 4 & 4 & 3 & 3 & 4 & 3 & 4 & 1 & 1 & 3 & 1 & 3 & 2 & 4 & 4 & 4 & 5 \\
\hline R18 & 4 & 3 & 4 & 2 & 2 & 4 & 2 & 4 & 2 & 2 & 3 & 3 & 2 & 3 & 2 & 5 & 2 & 4 & 2 & 2 \\
\hline
\end{tabular}




\begin{tabular}{|c|c|c|c|c|c|c|c|c|c|c|c|c|c|c|c|c|c|c|c|c|}
\hline R19 & 3 & 3 & 5 & 4 & 1 & 3 & 5 & 3 & 1 & 4 & 2 & 3 & 2 & 2 & 4 & 5 & 2 & 5 & 2 & 1 \\
\hline R20 & 3 & 4 & 4 & 3 & 4 & 1 & 2 & 2 & 1 & 2 & 2 & 2 & 4 & 2 & 3 & 2 & 3 & 3 & 3 & 2 \\
\hline R21 & 3 & 4 & 3 & 3 & 4 & 5 & 4 & 4 & 3 & 2 & 4 & 5 & 3 & 4 & 4 & 4 & 3 & 5 & 3 & 4 \\
\hline R22 & 2 & 4 & 5 & 3 & 1 & 1 & 3 & 2 & 1 & 2 & 2 & 2 & 3 & 2 & 3 & 4 & 2 & 4 & 4 & 2 \\
\hline R23 & 5 & 3 & 5 & 3 & 4 & 5 & 4 & 5 & 3 & 4 & 5 & 5 & 4 & 4 & 5 & 4 & 5 & 5 & 5 & 1 \\
\hline R24 & 2 & 4 & 5 & 4 & 1 & 5 & 5 & 4 & 5 & 5 & 5 & 5 & 4 & 5 & 4 & 4 & 4 & 5 & 5 & 4 \\
\hline R25 & 4 & 3 & 4 & 3 & 4 & 4 & 4 & 3 & 2 & 4 & 3 & 3 & 5 & 4 & 4 & 5 & 3 & 5 & 4 & 3 \\
\hline R26 & 4 & 3 & 4 & 5 & 1 & 4 & 5 & 3 & 4 & 4 & 3 & 1 & 5 & 3 & 3 & 5 & 3 & 5 & 4 & 2 \\
\hline R27 & 2 & 4 & 5 & 3 & 4 & 3 & 3 & 3 & 2 & 3 & 3 & 1 & 4 & 3 & 3 & 4 & 2 & 5 & 5 & 2 \\
\hline R28 & 4 & 3 & 3 & 5 & 1 & 4 & 4 & 3 & 4 & 4 & 3 & 3 & 5 & 4 & 4 & 5 & 2 & 5 & 3 & 4 \\
\hline R29 & 3 & 2 & 4 & 2 & 2 & 5 & 2 & 2 & 2 & 5 & 2 & 3 & 4 & 4 & 4 & 4 & 4 & 5 & 3 & 3 \\
\hline R30 & 4 & 4 & 4 & 3 & 4 & 5 & 5 & 2 & 4 & 5 & 2 & 4 & 5 & 5 & 5 & 5 & 5 & 5 & 5 & 1 \\
\hline R31 & 4 & 4 & 4 & 3 & 5 & 5 & 4 & 4 & 5 & 5 & 4 & 4 & 5 & 3 & 5 & 3 & 4 & 4 & 5 & 4 \\
\hline R32 & 5 & 4 & 4 & 5 & 4 & 1 & 4 & 4 & 4 & 1 & 4 & 3 & 3 & 3 & 2 & 4 & 2 & 5 & 4 & 3 \\
\hline R33 & 4 & 4 & 5 & 3 & 2 & 5 & 2 & 2 & 2 & 3 & 4 & 4 & 4 & 3 & 2 & 5 & 2 & 5 & 4 & 4 \\
\hline R34 & 2 & 2 & 4 & 1 & 2 & 1 & 2 & 1 & 1 & 2 & 2 & 1 & 2 & 4 & 3 & 5 & 2 & 2 & 2 & 3 \\
\hline R35 & 2 & 2 & 4 & 4 & 3 & 3 & 3 & 3 & 3 & 3 & 2 & 4 & 4 & 2 & 4 & 5 & 2 & 2 & 2 & 2 \\
\hline R36 & 4 & 4 & 4 & 3 & 4 & 5 & 3 & 2 & 2 & 5 & 4 & 4 & 4 & 4 & 2 & 3 & 2 & 4 & 2 & 2 \\
\hline R37 & 2 & 4 & 4 & 2 & 2 & 3 & 4 & 2 & 4 & 4 & 2 & 2 & 4 & 2 & 1 & 5 & 2 & 5 & 4 & 2 \\
\hline R38 & 3 & 2 & 4 & 2 & 4 & 3 & 4 & 4 & 4 & 4 & 4 & 2 & 2 & 4 & 1 & 4 & 2 & 4 & 2 & 4 \\
\hline R39 & 3 & 2 & 4 & 1 & 2 & 2 & 3 & 2 & 2 & 2 & 4 & 1 & 2 & 1 & 3 & 3 & 2 & 3 & 2 & 3 \\
\hline R40 & 4 & 4 & 4 & 2 & 2 & 4 & 3 & 2 & 2 & 4 & 4 & 4 & 4 & 4 & 2 & 4 & 4 & 3 & 4 & 4 \\
\hline R41 & 4 & 3 & 4 & 5 & 3 & 3 & 4 & 5 & 1 & 3 & 3 & 4 & 4 & 3 & 1 & 5 & 4 & 3 & 3 & 5 \\
\hline R42 & 4 & 3 & 5 & 4 & 4 & 3 & 3 & 4 & 3 & 4 & 1 & 1 & 3 & 1 & 3 & 2 & 4 & 4 & 4 & 5 \\
\hline R43 & 4 & 4 & 4 & 2 & 2 & 4 & 2 & 4 & 2 & 2 & 3 & 3 & 2 & 3 & 2 & 5 & 2 & 4 & 2 & 2 \\
\hline R44 & 3 & 4 & 5 & 4 & 1 & 3 & 5 & 3 & 1 & 4 & 2 & 3 & 2 & 2 & 4 & 5 & 2 & 5 & 2 & 1 \\
\hline R45 & 3 & 3 & 4 & 3 & 4 & 1 & 2 & 2 & 1 & 2 & 2 & 2 & 4 & 2 & 3 & 2 & 3 & 3 & 3 & 2 \\
\hline R46 & 3 & 3 & 3 & 3 & 4 & 5 & 4 & 4 & 3 & 2 & 4 & 5 & 3 & 4 & 4 & 4 & 3 & 5 & 3 & 4 \\
\hline R47 & 2 & 3 & 5 & 3 & 1 & 1 & 3 & 2 & 1 & 2 & 2 & 2 & 3 & 2 & 3 & 4 & 2 & 4 & 4 & 2 \\
\hline R48 & 5 & 5 & 5 & 4 & 1 & 5 & 2 & 4 & 4 & 4 & 5 & 5 & 5 & 5 & 4 & 4 & 4 & 5 & 5 & 3 \\
\hline R49 & 2 & 4 & 2 & 2 & 2 & 3 & 2 & 2 & 3 & 3 & 4 & 3 & 4 & 4 & 2 & 5 & 2 & 5 & 3 & 2 \\
\hline R50 & 4 & 3 & 5 & 5 & 3 & 2 & 2 & 3 & 2 & 4 & 1 & 4 & 4 & 1 & 1 & 3 & 3 & 5 & 5 & 2 \\
\hline R51 & 2 & 3 & 3 & 3 & 3 & 4 & 3 & 2 & 3 & 4 & 2 & 2 & 4 & 2 & 2 & 2 & 2 & 4 & 4 & 3 \\
\hline R52 & 3 & 4 & 4 & 2 & 3 & 4 & 2 & 2 & 1 & 4 & 2 & 2 & 3 & 2 & 2 & 5 & 2 & 4 & 4 & 3 \\
\hline R53 & 4 & 4 & 5 & 2 & 2 & 5 & 2 & 2 & 2 & 3 & 4 & 4 & 4 & 3 & 2 & 5 & 2 & 5 & 4 & 4 \\
\hline R54 & 2 & 2 & 4 & 1 & 1 & 1 & 2 & 1 & 1 & 2 & 2 & 1 & 2 & 4 & 3 & 5 & 2 & 2 & 2 & 3 \\
\hline R55 & 2 & 2 & 4 & 4 & 2 & 3 & 3 & 3 & 3 & 3 & 2 & 4 & 4 & 2 & 4 & 5 & 2 & 2 & 2 & 2 \\
\hline R56 & 4 & 4 & 4 & 3 & 3 & 5 & 3 & 2 & 2 & 5 & 4 & 4 & 4 & 4 & 2 & 3 & 2 & 4 & 2 & 2 \\
\hline R57 & 2 & 4 & 4 & 2 & 2 & 4 & 4 & 2 & 4 & 4 & 2 & 2 & 4 & 2 & 1 & 5 & 2 & 5 & 4 & 2 \\
\hline R58 & 3 & 2 & 4 & 2 & 4 & 4 & 4 & 4 & 4 & 4 & 4 & 2 & 2 & 4 & 1 & 4 & 2 & 4 & 2 & 4 \\
\hline R59 & 3 & 2 & 4 & 1 & 2 & 2 & 4 & 2 & 2 & 2 & 4 & 1 & 2 & 1 & 3 & 3 & 2 & 3 & 2 & 3 \\
\hline \multirow[t]{2}{*}{ R60 } & 4 & 4 & 4 & 2 & 2 & 4 & 4 & 2 & 2 & 4 & 4 & 4 & 4 & 4 & 2 & 4 & 4 & 3 & 4 & 4 \\
\hline & 198 & 206 & 245 & 179 & 158 & 205 & 191 & 170 & 152 & 201 & 174 & 175 & 207 & 177 & 169 & 237 & 162 & 248 & 204 & 169 \\
\hline
\end{tabular}

\begin{tabular}{|c|c|c|c|c|c|c|c|c|c|c|c|c|c|c|c|c|c|c|c|c|c|}
\hline Item & 21 & 22 & 23 & 24 & 25 & 26 & 27 & 28 & 29 & 30 & 31 & 32 & 33 & 34 & 35 & 36 & 37 & 38 & 39 & 40 & $\mathrm{Jml}$ \\
\hline $\mathrm{R} 1$ & 2 & 2 & 4 & 5 & 2 & 4 & 4 & 5 & 2 & 5 & 3 & 2 & 4 & 3 & 4 & 3 & 3 & 3 & 4 & 4 & 127 \\
\hline $\mathrm{R} 2$ & 5 & 4 & 3 & 5 & 4 & 3 & 3 & 3 & 4 & 5 & 4 & 3 & 4 & 5 & 3 & 4 & 4 & 4 & 5 & 3 & 149 \\
\hline R3 & 4 & 3 & 2 & 4 & 2 & 2 & 4 & 1 & 3 & 5 & 2 & 4 & 2 & 2 & 2 & 3 & 2 & 2 & 3 & 2 & 122 \\
\hline $\mathrm{R} 4$ & 2 & 2 & 4 & 5 & 4 & 4 & 4 & 4 & 2 & 5 & 2 & 3 & 2 & 4 & 4 & 4 & 4 & 2 & 4 & 4 & 139 \\
\hline R5 & 3 & 3 & 4 & 4 & 3 & 2 & 3 & 4 & 4 & 4 & 4 & 4 & 4 & 4 & 4 & 5 & 4 & 4 & 4 & 2 & 137 \\
\hline R6 & 1 & 1 & 2 & 2 & 1 & 1 & 1 & 2 & 1 & 1 & 1 & 1 & 2 & 3 & 1 & 2 & 3 & 1 & 3 & 1 & 62 \\
\hline R7 & 3 & 2 & 1 & 5 & 1 & 3 & 3 & 4 & 4 & 3 & 2 & 5 & 5 & 4 & 5 & 2 & 4 & 2 & 3 & 3 & 130 \\
\hline R8 & 3 & 3 & 2 & 4 & 2 & 2 & 2 & 3 & 3 & 2 & 2 & 4 & 3 & 2 & 3 & 3 & 2 & 2 & 3 & 2 & 115 \\
\hline R9 & 5 & 5 & 5 & 4 & 4 & 5 & 5 & 5 & 1 & 1 & 5 & 5 & 4 & 4 & 5 & 3 & 2 & 4 & 4 & 4 & 154 \\
\hline R10 & 1 & 5 & 1 & 1 & 1 & 2 & 2 & 3 & 2 & 2 & 3 & 2 & 4 & 5 & 3 & 3 & 3 & 2 & 4 & 3 & 104 \\
\hline R11 & 4 & 5 & 4 & 4 & 5 & 4 & 5 & 3 & 1 & 5 & 3 & 4 & 5 & 4 & 4 & 4 & 3 & 2 & 5 & 2 & 159 \\
\hline R12 & 2 & 5 & 4 & 3 & 1 & 2 & 2 & 3 & 2 & 4 & 4 & 4 & 5 & 3 & 4 & 4 & 3 & 3 & 5 & 4 & 127 \\
\hline R13 & 1 & 5 & 5 & 4 & 4 & 2 & 3 & 4 & 3 & 4 & 2 & 4 & 4 & 2 & 2 & 3 & 4 & 3 & 4 & 4 & 128 \\
\hline R14 & 5 & 5 & 4 & 2 & 5 & 1 & 3 & 3 & 3 & 4 & 4 & 4 & 5 & 4 & 4 & 3 & 3 & 3 & 5 & 3 & 132 \\
\hline R15 & 2 & 5 & 5 & 3 & 3 & 5 & 1 & 3 & 1 & 4 & 4 & 4 & 5 & 3 & 4 & 4 & 3 & 5 & 5 & 4 & 132 \\
\hline R16 & 1 & 4 & 3 & 3 & 4 & 3 & 2 & 4 & 2 & 1 & 2 & 1 & 5 & 3 & 4 & 3 & 3 & 2 & 5 & 3 & 129 \\
\hline R17 & 4 & 4 & 4 & 2 & 4 & 3 & 4 & 3 & 4 & 1 & 4 & 4 & 3 & 4 & 3 & 3 & 3 & 2 & 3 & 4 & 133 \\
\hline $\mathrm{R} 18$ & 2 & 5 & 4 & 2 & 4 & 2 & 4 & 5 & 4 & 2 & 4 & 4 & 5 & 3 & 5 & 3 & 4 & 3 & 5 & 3 & 130 \\
\hline R19 & 2 & 5 & 4 & 3 & 2 & 5 & 1 & 2 & 1 & 4 & 2 & 4 & 4 & 2 & 4 & 3 & 2 & 2 & 4 & 2 & 118 \\
\hline R20 & 1 & 1 & 4 & 4 & 3 & 4 & 1 & 2 & 1 & 3 & 3 & 3 & 3 & 3 & 3 & 3 & 2 & 4 & 3 & 3 & 106 \\
\hline R21 & 5 & 5 & 5 & 4 & 4 & 5 & 5 & 5 & 1 & 1 & 5 & 5 & 4 & 4 & 5 & 3 & 2 & 4 & 4 & 4 & 154 \\
\hline R22 & 1 & 5 & 1 & 1 & 1 & 2 & 2 & 3 & 2 & 2 & 3 & 2 & 4 & 5 & 3 & 3 & 3 & 2 & 4 & 3 & 104 \\
\hline R23 & 4 & 5 & 5 & 4 & 5 & 5 & 5 & 5 & 5 & 5 & 5 & 5 & 5 & 5 & 5 & 3 & 5 & 4 & 5 & 5 & 179 \\
\hline R24 & 5 & 5 & 4 & 4 & 4 & 5 & 5 & 3 & 5 & 5 & 3 & 4 & 5 & 1 & 5 & 4 & 5 & 3 & 3 & 4 & 167 \\
\hline R25 & 1 & 3 & 4 & 4 & 1 & 4 & 4 & 3 & 4 & 3 & 3 & 3 & 4 & 3 & 3 & 2 & 3 & 3 & 2 & 4 & 135 \\
\hline
\end{tabular}




\begin{tabular}{|c|c|c|c|c|c|c|c|c|c|c|c|c|c|c|c|c|c|c|c|c|c|}
\hline R26 & 1 & 2 & 4 & 2 & 1 & 5 & 2 & 4 & 5 & 5 & 4 & 5 & 5 & 2 & 3 & 1 & 2 & 4 & 3 & 4 & 135 \\
\hline R27 & 2 & 2 & 4 & 3 & 2 & 3 & 3 & 3 & 3 & 4 & 3 & 4 & 3 & 3 & 3 & 2 & 3 & 3 & 4 & 4 & 125 \\
\hline R28 & 1 & 4 & 2 & 4 & 1 & 4 & 4 & 2 & 4 & 1 & 2 & 5 & 5 & 2 & 2 & 3 & 2 & 2 & 3 & 2 & 128 \\
\hline R29 & 2 & 3 & 3 & 3 & 2 & 4 & 3 & 3 & 4 & 3 & 3 & 3 & 3 & 2 & 2 & 4 & 2 & 3 & 2 & 3 & 122 \\
\hline R30 & 4 & 5 & 4 & 5 & 2 & 4 & 2 & 3 & 4 & 1 & 3 & 4 & 4 & 5 & 3 & 5 & 3 & 3 & 4 & 4 & 154 \\
\hline R31 & 5 & 5 & 5 & 5 & 5 & 5 & 5 & 4 & 5 & 5 & 4 & 5 & 5 & 5 & 4 & 5 & 5 & 4 & 4 & 5 & 179 \\
\hline R32 & 1 & 3 & 4 & 3 & 1 & 4 & 3 & 4 & 4 & 4 & 3 & 2 & 4 & 3 & 2 & 4 & 3 & 3 & 4 & 4 & 132 \\
\hline R33 & 4 & 5 & 4 & 3 & 3 & 2 & 2 & 5 & 2 & 1 & 4 & 4 & 4 & 2 & 4 & 4 & 4 & 4 & 4 & 4 & 138 \\
\hline R34 & 1 & 1 & 1 & 4 & 1 & 2 & 1 & 2 & 1 & 1 & 1 & 4 & 5 & 1 & 1 & 2 & 1 & 1 & 2 & 2 & 79 \\
\hline R35 & 3 & 5 & 2 & 3 & 2 & 4 & 3 & 4 & 3 & 4 & 4 & 4 & 3 & 4 & 4 & 2 & 4 & 2 & 2 & 3 & 124 \\
\hline R36 & 1 & 5 & 4 & 2 & 2 & 4 & 4 & 1 & 4 & 2 & 3 & 2 & 5 & 3 & 3 & 4 & 3 & 4 & 4 & 4 & 131 \\
\hline R37 & 5 & 4 & 2 & 2 & 3 & 4 & 2 & 2 & 2 & 4 & 1 & 4 & 4 & 1 & 4 & 2 & 4 & 2 & 4 & 3 & 119 \\
\hline R38 & 1 & 5 & 2 & 3 & 3 & 4 & 3 & 2 & 4 & 4 & 2 & 4 & 2 & 3 & 3 & 4 & 3 & 2 & 2 & 4 & 123 \\
\hline R39 & 1 & 2 & 4 & 4 & 3 & 3 & 4 & 2 & 3 & 1 & 2 & 4 & 3 & 3 & 3 & 3 & 3 & 2 & 2 & 4 & 103 \\
\hline R40 & 2 & 4 & 2 & 3 & 2 & 2 & 3 & 3 & 2 & 2 & 3 & 2 & 5 & 2 & 2 & 2 & 2 & 3 & 4 & 2 & 120 \\
\hline R41 & 1 & 4 & 3 & 3 & 4 & 3 & 2 & 4 & 2 & 1 & 2 & 1 & 5 & 3 & 4 & 3 & 3 & 2 & 5 & 3 & 128 \\
\hline R42 & 4 & 4 & 4 & 2 & 4 & 3 & 4 & 3 & 4 & 1 & 4 & 4 & 3 & 4 & 3 & 3 & 3 & 2 & 3 & 4 & 131 \\
\hline R43 & 2 & 5 & 4 & 2 & 4 & 2 & 4 & 5 & 4 & 2 & 4 & 4 & 5 & 3 & 5 & 3 & 4 & 3 & 5 & 3 & 131 \\
\hline R44 & 2 & 5 & 4 & 3 & 2 & 5 & 1 & 2 & 1 & 4 & 2 & 4 & 4 & 2 & 4 & 3 & 2 & 2 & 4 & 2 & 119 \\
\hline R45 & 1 & 1 & 4 & 4 & 3 & 4 & 1 & 2 & 1 & 3 & 3 & 3 & 3 & 3 & 3 & 3 & 2 & 4 & 3 & 3 & 105 \\
\hline R46 & 5 & 5 & 5 & 4 & 4 & 5 & 5 & 5 & 1 & 1 & 5 & 5 & 4 & 4 & 5 & 3 & 2 & 4 & 4 & 4 & 153 \\
\hline R47 & 1 & 5 & 1 & 1 & 1 & 2 & 2 & 3 & 2 & 2 & 3 & 2 & 4 & 5 & 3 & 3 & 3 & 2 & 4 & 3 & 103 \\
\hline R48 & 4 & 5 & 4 & 4 & 5 & 4 & 5 & 3 & 1 & 5 & 3 & 4 & 5 & 4 & 4 & 4 & 3 & 2 & 5 & 2 & 160 \\
\hline R49 & 2 & 5 & 4 & 3 & 1 & 2 & 2 & 3 & 2 & 4 & 4 & 4 & 5 & 3 & 4 & 4 & 3 & 3 & 5 & 4 & 126 \\
\hline R50 & 1 & 5 & 5 & 4 & 4 & 2 & 3 & 4 & 3 & 4 & 2 & 4 & 4 & 2 & 2 & 3 & 4 & 3 & 4 & 4 & 129 \\
\hline R51 & 5 & 5 & 4 & 2 & 5 & 1 & 3 & 3 & 3 & 4 & 4 & 4 & 5 & 4 & 4 & 3 & 3 & 3 & 5 & 3 & 130 \\
\hline R52 & 2 & 5 & 5 & 3 & 3 & 5 & 1 & 3 & 1 & 4 & 4 & 4 & 5 & 3 & 4 & 4 & 3 & 5 & 5 & 4 & 131 \\
\hline R53 & 4 & 5 & 4 & 3 & 3 & 2 & 2 & 5 & 2 & 1 & 4 & 4 & 4 & 2 & 4 & 4 & 4 & 4 & 4 & 4 & 137 \\
\hline R54 & 1 & 1 & 1 & 4 & 1 & 2 & 1 & 2 & 1 & 1 & 1 & 4 & 5 & 1 & 1 & 2 & 1 & 1 & 2 & 2 & 78 \\
\hline R55 & 3 & 5 & 2 & 3 & 2 & 4 & 3 & 4 & 3 & 4 & 4 & 4 & 3 & 4 & 4 & 2 & 4 & 2 & 2 & 3 & 123 \\
\hline R56 & 1 & 5 & 4 & 2 & 2 & 4 & 4 & 1 & 4 & 2 & 3 & 2 & 5 & 3 & 3 & 4 & 3 & 4 & 4 & 4 & 130 \\
\hline R57 & 5 & 4 & 2 & 2 & 3 & 4 & 2 & 2 & 2 & 4 & 1 & 4 & 4 & 1 & 4 & 2 & 4 & 2 & 4 & 3 & 120 \\
\hline R58 & 1 & 5 & 2 & 3 & 3 & 4 & 3 & 2 & 4 & 4 & 2 & 4 & 2 & 3 & 3 & 4 & 3 & 2 & 2 & 4 & 124 \\
\hline R59 & 1 & 2 & 4 & 4 & 3 & 3 & 4 & 2 & 3 & 1 & 2 & 4 & 3 & 3 & 3 & 3 & 3 & 2 & 2 & 4 & 104 \\
\hline \multirow[t]{2}{*}{$\mathrm{R} 60$} & 2 & 4 & 2 & 3 & 2 & 2 & 3 & 3 & 2 & 2 & 3 & 2 & 5 & 2 & 2 & 2 & 2 & 3 & 4 & 2 & 121 \\
\hline & 151 & 237 & 203 & 194 & 166 & 197 & 177 & 190 & 161 & 177 & 181 & 215 & 243 & 185 & 204 & 189 & 182 & 168 & 223 & 197 & 7667 \\
\hline
\end{tabular}

Untuk melakukan validitas empirik pada data yang berjenis politomi, digunakan rumus product moment seperti berikut ini.

$$
r_{x y}=\frac{N \sum X Y-\left(\sum X\right)\left(\sum Y\right)}{\sqrt{\left\{N \sum X^{2}-\left(\sum X\right)^{2}\right)\left\{N \sum Y^{2}-\left(\sum Y\right)^{2}\right\}}}
$$

(Candiasa, 2010:116)

\section{Keterangan:}

$\mathrm{N}=$ banyaknya responden atau peserta

$\mathrm{X}=$ skor responden untuk butir yang dicari validitasnya

$Y=$ skor total responden $r_{x y}=$ nilai koefisien korelasi product moment

Penentuan suatu butir instrumen dinyatakan valid atau tidak valid, adalah dengan membandingkan koefisien $r_{x y}=r_{\text {hitung }}$ dengan $r_{x y}$ tabel. Butir dikatakan "valid" jika nilai $r_{x y}=r_{\text {hitung }}$ lebih besar dari $r_{x y}$ tabel dengan taraf signifikansi $\alpha=5 \%\left(r_{x y^{-}}\right.$ hit $\geq r_{x y}$-tab dengan t.s 5\%), dan "tidak valid" jika nilai $r_{x y}=r_{\text {hitung }}$ lebih besar dari $r_{x y}$ tabel dengan taraf signifikansi $\alpha=5 \%\left(r_{x y^{-}}\right.$ hit $<r_{x y}$-tab dengan t.s 5\%).

Sebagai contoh adalah untuk mencari validitas butir ke-2. Untuk butir kedua, diperoleh skor total dari seluruh responden adalah 151 dan skor total dari seluruh responden adalah 7667. Berdasarkan rumus product moment maka diperoleh angka-angka dari masingmasing variabel berdaarkan Tabel 3 adalah sebagai berikut.

$\mathrm{N}=60, \quad \sum \mathrm{X}=206, \quad \sum \mathrm{Y}=7667, \quad \sum \mathrm{XY}=26790$, $\sum X^{2}=750, \sum Y^{2}=1006147$

Dengan demikian dapat dihitung dengan rumus product moment sebagai berikut. $\mathrm{r}_{\mathrm{xy}}=60 * 26790-206 * 7667 / \sqrt{ }\{(60 * 750-$ $\left.206 * 206)\left(60^{\star} 1006147-7667^{\star} 7667\right)\right\}$ $r_{x y}=27998 / \sqrt{ }(4066327084)=0,439$ 
Sesuai hasil perhitungan koefisien korelasi product moment untuk butir ke-2 diperoleh harga $r_{x y}=0,439$, sedangkan $r_{x y}$ tabel pada taraf signifikansi $\alpha=5 \%$ dan $n=$ 60 adalah 0,254. Berdasarkan perhitungan harga $r_{x y}$ hitung lebih besar daripada harga $r_{x y}$ tabel, maka jumlah skor butir ke2 mempunyai korelasi yang signifikan dengan jumlah skor total. Oleh sebab itu, dapat diinterpretasikan bahwa butir nomor 2 adalah valid. Contoh lainnya adalah untuk menghitung validitas butir ke-20. Dengan cara yang sama pada perhitungan sebelumnya diperoleh hasil perhitungan koefisien korelasi product moment untuk butir ke-20 diperoleh harga $r_{x y}=0,123$, sedangkan $r_{x y}$ tabel pada taraf signifikansi $\alpha=5 \%$ dan $n=60$ adalah 0,254. Berdasarkan hasil perhitungan harga $r_{x y}$ hitung lebih kecil daripada harga $r_{x y}$ tabel, maka jumlah skor butir ke-20 tidak berkorelasi signifikan dengan jumlah skor total. Oleh sebab itu, dapat diinterpretasikan bahwa butir nomor 20 adalah tidak valid atau drop. Setelah dilakukan pengujian validitas butir kuesioner kecerdasan logis-matematis yang berjumlah 40 butir terhadap 60 responden, ternyata terdapat 3 butir pernyataan yang tidak valid, yaitu butir nomor 3, 16 dan 20. Oleh sebab itu, butir pernyataan tersebut harus dibuang atau tidak dapat digunakan lebih lanjut.

Langkah selanjutnya adalah perhitungan koefisien reliabilitas instrumen atas butir-butir instrumen yang valid. Perhitungan koefisien reliabilitas instrumen menggunakan rumus koefisien Alpha-Cronbach seperti berikut ini.

$r_{i i}=\left(\frac{k}{k-1}\right)\left(1-\frac{\sum S_{i}^{2}}{S_{t}^{2}}\right)$

(Djaali dan Muljono, 2008:49)

Keterangan:

$r_{i i}=$ koefisien reliabilitas tes

$\mathrm{k}=$ cacah butir

$\mathrm{S}^{2}=$ varians skor butir

$\mathrm{S}_{\mathrm{t}}^{2}=$ varians skor total

Sebagai catatan dalam perhitungan reliabilitas ini bahwa, untuk menghitung reliabilitas instrumen menggunakan rumus di atas adalah untuk butir-butir yang valid saja. Sementara untuk butir-butir instrumen yang tidak valid harus dibuang. Berdasarkan hasil perhitungan dengan bantuan program Microsoft Excel 2007, diperoleh angka-angka sebagai berikut.

$\mathrm{K}=60$, SD Skor Butir=66,10, SD Skor Total $=440,53$. Sehingga dengan demikian, diperoleh reliabilitas instrumen sama dengan:

$$
\begin{aligned}
& r_{i i}=(60 / 59)^{*}(1-(66,10 / 440,53)) \\
& r_{i i}=0,86
\end{aligned}
$$

Dari hasil perhitungan tersebut menunjukkan bahwa tingkat reliabilitas instrumen kecerdasan logis-matematis adalah sebesar 0,86. Dengan demikian, hasil uji coba menunjukkan bahwa koefisien reliabilitas instrumen kecerdasan logis-matematis lebih besar dari 0,7, sehingga dapat digunakan lebih lanjut.

\section{SIMPULAN DAN SARAN}

Berdasarkan hasil analisis dan pembahasan yang telah dilakukan, dapat ditarik kesimpulan sebagai berikut. Instrumen kecerdasan logis-matematis yang telah dikembangkan dapat digunakan lebih lanjut dalam penelitian. Hal ini dapat dilihat dari koefisien reliabilitas instrumen sebesar 0,853 lebih besar dari yang dipersyaratkan yaitu sebesar 0,7. Berdasarkan hasil analisis, dari 40 butir instrumen yang dikembangkan, hanya 37 yang valid berdasarkan hasil ujicoba. Namun demikian, instrumen sudah dapat digunakan karena butir-butir yang valid telah mewakili semua indikator yang ada.

\section{DAFTAR PUSTAKA}

Armstrong, T. 2013. Kecerdasan Multipel di dalam Kelas, terjemahan Dyah Widya Prabaningrum. Jakarta: PT Indeks.

Budiningsih, C. A. 2012. Belajar \& Pembelajaran. Jakarta: Rineka Cipta.

Candiasa, I. M. 2010. Pengujian Instrumen Penelitian Disertai Aplikasi ITEMAN dan BIGSTEPS. Singaraja: Unit 
Penerbitan Universitas Pendidikan Ganesha.

Djaali, H., \& Muljono, P. 2008. Pengukuran dalam Bidang Pendidikan. Jakarta: Grasindo.

Gardner, H. 2003. Multiple Intelligences, terjemahan Alexander Sindoro. Batam: Interaksara.

Gregory, R. J. 2000. Psychological Testing: History, Principles, and Applications. Boston: Allyn and Bacon.

Iskandar. 2012. Psikologi Pendidikan Sebuah Orientasi Baru. Jakarta: Referensi.

Jasmine, J. 2012. Metode Mengajar Multiple Intelligences, terjemahan Purwanto. Bandung: Nuansa Cendekia.

Setemen, K. 2014. Pengaruh Jenis Asesmen Terhadap Hasil Belajar Pemrograman Komputer. Seminar Nasional Forum Pimpinan Pascasarjana LPTK Indonesia (pp. 38-42). Bali: Pascasarjana UNDIKSHA.

Suparno, P. 2004. Teori Inteligensi Ganda dan Aplikasinya di Sekolah. Yogyakarta: Kanisius.

Riyanto, Y. 2010. Paradigma Baru Pembelajaran. Jakarta: Prenada Media Group. 